\title{
Is Poverty in Our Genes?
}

\section{Citation}

D' Alpoim Guedes, Jade, Theodore C. Bestor, David Carrasco, Rowan Flad, Ethan Fosse, Michael Herzfeld, Carl C. Lamberg-Karlovsky, et al. 2013. "Is Poverty in Our Genes?" Current Anthropology 54 (1) (February): 71-79. doi:10.1086/669034.

\section{Published Version}

doi:10.1086/669034

\section{Permanent link}

http://nrs.harvard.edu/urn-3:HUL.InstRepos:32192696

\section{Terms of Use}

This article was downloaded from Harvard University's DASH repository, and is made available under the terms and conditions applicable to Other Posted Material, as set forth at http:// nrs.harvard.edu/urn-3:HUL.InstRepos:dash.current.terms-of-use\#LAA

\section{Share Your Story}

The Harvard community has made this article openly available.

Please share how this access benefits you. Submit a story.

Accessibility 


\title{
CA々 FORUM ON PUBLIC ANTHROPOLOGY
}

\section{Is Poverty in Our Genes?}

\section{A Critique of Ashraf and Galor, "The 'Out of Africa' Hypothesis, Human Genetic Diversity, and Comparative Economic Development," American Economic Review (Forthcoming) ${ }^{1}$}

\author{
by Jade d'Alpoim Guedes, Theodore C. Bestor, David Carrasco, \\ Rowan Flad, Ethan Fosse, Michael Herzfeld, Carl C. Lamberg-Karlovsky, \\ Cecil M. Lewis, Matthew Liebmann, Richard Meadow, Nick Patterson, \\ Max Price, Meredith Reiches, Sarah Richardson, \\ Heather Shattuck-Heidorn, Jason Ur, Gary Urton, \\ and Christina Warinner
}

\begin{abstract}
We present a critique of a paper written by two economists, Quamrul Ashraf and Oded Galor, which is forthcoming in the American Economic Review and which was uncritically highlighted in Science magazine. Their paper claims there is a causal effect of genetic diversity on economic success, positing that too much or too little genetic diversity constrains development. In particular, they argue that "the high degree of diversity among African populations and the low degree of diversity among Native American populations have been a detrimental force in the development of these regions." We demonstrate that their argument is seriously flawed on both factual and methodological grounds. As economists and other social scientists begin exploring newly available genetic data, it is crucial to remember that nonexperts broadcasting bold claims on the basis of weak data and methods can have profoundly detrimental social and political effects.
\end{abstract}

Explanations for human behavior based on genetic data are powerful and intuitive, but their mobilization comes with responsibility. Since the completion of the full sequencing of the human genome in 2003, several economists have begun to revisit the idea that economic outcomes can be related to genetic background (Ashraf and Galor 2013; Benjamin et al. 2007; Clark

Jade d'Alpoim Guedes is a $\mathrm{PhD}$ candidate in the Department of Anthropology at Harvard University (11 Divinity Avenue, Cambridge, Massachusetts 02138, U.S.A. [jguedes@fas.harvard.edu]). Theodore C. Bestor is Reischauer Institute Professor of Social Anthropology in the Department of Anthropology at Harvard University (William James Hall, 33 Kirkland Street, Cambridge, Massachusetts 02138, U.S.A.). David Carrasco is Neil L. Rudenstine Professor for the Study of Latin America and Rowan Flad is Professor in the Department of Anthropology at Harvard University (11 Divinity Avenue, Cambridge, Massachusetts 02138, U.S.A.). Ethan Fosse is a $\mathrm{PhD}$ candidate in the Department of Sociology at Harvard University (William James Hall, 33 Kirkland Street, Cambridge, Massachusetts 02138, U.S.A.). Michael Herzfeld is Ernest E. Monrad
2007). While studies based on high-quality data and robust methods have advanced anthropology, economics, and other social sciences, studies based on poor data and faulty methods - that is, "bad science"-are pervasive and pernicious.

With this in mind, we present here a critique of a paper written by two economists, Quamrul Ashraf and Oded Galor, which is

Professor of the Social Sciences in the Department of Anthropology at Harvard University (William James Hall, 33 Kirkland Street, Cambridge, Massachusetts 02138, U.S.A.). Carl C. LambergKarlovsky is Stephen Phillips Professor of Archaeology and Ethnology in the Department of Anthropology at Harvard University (11 Divinity Avenue, Cambridge, Massachusetts 02138, U.S.A.). Cecil M. Lewis is Associate Professor in the Department of Anthropology of the Stephenson Research and Technology Center of the University of Oklahoma (101 David L. Boren Boulevard, Norman, Oklahoma 73019, U.S.A.). Matthew Liebmann is Assistant Professor in the Department of Anthropology at Harvard University (11 Divinity

1. Ashraf and Galor's paper is tentatively scheduled to be published in volume 103, issue 1 (February 2013) of the American Economic Review. 
forthcoming in the American Economic Review, uncritically highlighted in Science on September 7, 2012 (Chin 2012) and featured in Nature on October 10, 2012 (Callaway 2012). We wrote an initial summary outlining our concerns, which was published online (d'Alpoim Guedes et al. 2012) and to which Ashraf and Galor (2012) replied. In their paper, Ashraf and Galor (2013) claim there is a causal effect of genetic diversity on economic success, positing that too much or too little genetic diversity constrains development. In this paper, we demonstrate that their argument is seriously flawed on both factual and methodological grounds. As economists and other social scientists begin exploring newly available genetic data, it is crucial to remember that nonexperts broadcasting bold claims about genetic effects on the basis of weak data and methods can have profoundly detrimental social and political effects.

\section{Summary of Ashraf and Galor Paper}

The forthcoming study by Ashraf and Galor contends that the level of genetic diversity (heterozygosity) present in a population causes long-lasting effects on economic development. They assert that genetic diversity accounts for " $16 \%$ of cross-country dispersion in per-capita income" (Chin 2012: 1150). The authors further posit an "optimal" genetic diversity level for economic success, which incidentally favors Eurasian populations (Ashraf and Galor 2013). Genetic diversity, they maintain, affects economic development in two countervailing ways. On the one hand, high levels of genetic het-

Avenue, Cambridge, Massachusetts 02138, U.S.A.). Richard Meadow is Senior Lecturer and Director of the Zooarchaeology Laboratory in the Peabody Museum at Harvard University (Department of Anthropology, 11 Divinity Avenue, Cambridge, Massachusetts 02138, U.S.A.). Nick Patterson is Senior Computational Biologist at the Broad Institute (7 Cambridge Center, Cambridge, Massachusetts 02142, U.S.A.). Max Price is a PhD student in the Department of Anthropology at Harvard University (11 Divinity Avenue, Cambridge, Massachusetts 02138, U.S.A.). Meredith Reiches is a postdoctoral fellow in the Department of Human Evolutionary Biology at Harvard University (11 Divinity Avenue, Cambridge, Massachusetts 02138, U.S.A.). Sarah Richardson is an Assistant Professor in the Department of the History of Science at Harvard University (Science Center 371, Cambridge, Massachusetts 02138, U.S.A.). Heather Shattuck-Heidorn is a $\mathrm{PhD}$ student in the Department of Human Evolutionary Biology at Harvard University (11 Divinity Avenue, Cambridge, Massachusetts 02138, U.S.A.). Jason Ur is John L. Loeb Associate Professor of the Social Sciences and Gary Urton is Dumbarton Oaks Professor of Pre-Columbian Studies and Chair of the Department of Anthropology at Harvard University (11 Divinity Avenue, Cambridge, Massachusetts 02138, U.S.A.). Christina Warinner is a postdoctoral research associate in the Department of Anthropology of the Stephenson Research and Technology Center at the University of Oklahoma (101 David L. Boren Boulevard, Norman, Oklahoma 73019, U.S.A.). This paper was submitted 24 X 12, accepted 25 X 12, and electronically published 19 XII 12. erogeneity increase "the likelihood of miscoordination, distrust, reduces cooperation and disrupts the socio-economic order. ... Greater population diversity is thus interpreted as being associated with lower productivity" (Ashraf and Galor 2013). On the other hand, heterogeneity increases competition, driving technological advancement; thus, the "beneficial effect of diversity" plays a "positive role ... in the expansion of society's production possibility frontier" (Ashraf and Galor 2013).

After applying data transformations to adjust for factors such as the timing of the origins of agriculture (see their app. F4) and land productivity measures (app. F5) as well as institutional, cultural, and human capital variables in the analysis of contemporary populations (app. F6), Ashraf and Galor examine the relationship between genetic diversity and income per capita in $2000 \mathrm{CE}$ and population densities at three time points (1 $\mathrm{CE}, 1000 \mathrm{CE}$, and $1500 \mathrm{CE}$ ) based on population estimates from McEvedy and Jones (1978). The authors initially conduct their analysis on genetic data from 21 countries based on 53 ethnic groups (Ashraf and Galor 2013, app. E) reported in Ramachandran et al. (2005) from the HGDP-CEPH (Human Genome Diversity Project-Centre d'Etude de Polymorphisme Humain) Human Diversity Cell Line Panel (Cann et al. 2002). The authors attempt to bolster their claim for causality by using a so-called instrumental variable regression, in which a putatively "exogenous" variable is used to indirectly estimate a causal effect. Based on this method, the authors use a constructed measure of geographic distance along hypothetical migration routes ("migratory distance") from East Africa as an instrumental variable for the average heterozygosity index $(\mathrm{H})$ of each population estimated from a genome-wide panel of single nucleotide polymorphisms (SNPs), microsatellites, indels, and copy number variations (CNVs). Because their constructed genetic heterogeneity data are limited to only 21 countries, the authors then use estimates derived from this analysis of average heterozygosity index on migratory distance to fill in the missing values of their average heterozygosity index for an additional 124 countries (app. F2).

The authors find a "hump shaped relationship" (Ashraf and Galor 2013) between both heterozygosity and income per capita in $2000 \mathrm{CE}$, as well as between heterozygosity and estimated population density in their three historical periods. This leads the authors to posit an optimum level of genetic diversity in a population whereby Eurasian countries, which have intermediate levels of genetic diversity, have the highest levels of population density and per capita income, while "the high degree of diversity among African populations and the low degree of diversity among Native American populations have been a detrimental force in the development of these regions" (Ashraf and Galor 2013, abstract). The authors conclude by suggesting that European colonialism played a positive role in economic development: "cross-country migrations (linked to colonialism) altered genetic diversity and hence composition of human capital in colonized countries ... [and] the level of diversity that existed in these locations 
during the pre-colonial era changed substantially, towards the optimum level for development" (Ashraf and Galor 2013, emphasis added).

Ashraf and Galor's study is flawed in three main ways. First, they consistently misuse scientific terminology and concepts; in particular, their understanding of the relationship between migratory distance and genetic diversity is incorrect. Second, their additional data, including population density and various additional variables, are full of factual errors, missing or faulty references, and simplistic assumptions. Finally, their theory is inconsistent with the rich data and robust findings in anthropology, genetics, and sociology on human evolution, cooperation, and innovation, almost none of which they cite.

\section{Critique}

\section{Misunderstanding of Scientific Terminology and Concepts}

Ashraf and Galor's description of the human pattern of global genetic diversity is consistently inaccurate, leading to concerns that the authors do not understand the data they are attempting to characterize. For example, they repeatedly contend that "migratory distance" to various settlements across the globe affected genetic diversity. This is misleading. The pattern of human genetic diversity they are referring to was primarily affected by the sequential series of founder effects that occurred during the peopling of the world; geographic distance is largely a proxy for these founder effects (Ramachandran et al. 2005). This proxy is accurate for roughly predicting global trends of genetic diversity on a continental scale but does not predict regional genetic diversity within continents. Human populations, stratified by heterozygosity, can be grouped into just four classes: Africa, West Eurasia, East Eurasia, and a fourth class comprising the remaining populations, nearly all of which have low heterozygosity. This class includes Native American populations. We prefer to use sequence data rather than genotype data to measure heterozygosity, as this avoids ascertainment issues involving the choice of SNPs used. Table S36 of Meyer et al. (2012), which used high coverage sequence data from 11 humans, shows the pattern clearly. In other words, genetic diversity varies on a continental scale, with Africa the most diverse, the Americas the least, and Eurasia having intermediate values. No amount of regression analysis and bootstrapping can alter the fact that, in essence, Ashraf and Galor are working with only four data points: Africa, Europe, Asia, and the Americas. This would be the case even if the raw data of Ashraf and Galor were perfect and free of noise.

While Ashraf and Galor acknowledge that serial founder events play a causal role in shaping global genetic diversity, they fail to integrate the larger concept into their analysis and instead continue to describe "migratory distance" as having "adverse effects" on genetic diversity. For one, "adverse" is inaccurate phrasing because a reduction or an increase in genetic differentiation need not be thought of as beneficial or adverse. But more importantly, it is not the distance that is thought to have the primary effect, but rather the founder effect itself. It is for this reason that the "predicted genetic homogeneity" estimates for subcontinental populations presented in Ashraf and Galor's figure 4 have no demonstrated scientific basis.

Finally, despite making unambiguous statements about the causal role of genetic diversity in economic success in their original paper, ${ }^{2}$ in their reply to our criticism (d'Alpoim Guedes et al. 2012), Ashraf and Galor (2012:2) claim that "the measure of intra-population genetic diversity that we employ should be interpreted as a proxy (i.e., a correlated summary measure) for diversity amongst individuals in a myriad of observable and unobservable personal traits that may be physiological, behavioral, socially-constructed, or otherwise." However, Ashraf and Galor have not shown any data indicating that genetic diversity is somehow linked to "diversity more broadly defined" (Ashraf and Galor 2012:2) or what this might mean. They thus make a conceptual leap from a strict genetic definition of diversity (heterozygosity) to a common usage of diversity. Their statement fails to make sense with respect to alleles and their impact on behavior and biology.

\section{Factual Errors in Data}

Ignoring for the moment the fact that Ashraf and Galor have made a serious error in their interpretation of genetic diversity and migratory distance, the remaining variables in their model, including prehistoric population densities and geographic control factors, are poorly chosen. They do not reference the broader literature in archaeology or anthropology and thus demonstrate a critical lack of knowledge. Moreover, their poor choice of data sources leads to serious inaccuracies in their dependent variable of population density as well as in their control variables.

Problems with population density estimates. Ashraf and Galor (2013) use population density as a proxy for economic success in $1500 \mathrm{CE}$ (as well as in $1 \mathrm{CE}$ and $1000 \mathrm{CE}$, in their appendix).

2. For example: "The direct effect of genetic diversity on contemporary income per capita, once institutional, cultural, and geographical factors are accounted for, indicates that: (i) increasing the diversity of the most homogenous country in the sample (Bolivia) by 1 percentage point would raise its income per capita in the year $2000 \mathrm{CE}$ by 41 percent, (ii) decreasing the diversity of the most diverse country in the sample (Ethiopia) by 1 percentage point would raise its income per capita by 21 percent, (iii) a 1 percentage point change in genetic diversity (in either direction) at the optimum level of 0.721 (that most closely resembles the diversity level of the U.S.) would lower income per capita by 1.9 percent, (iv) increasing Bolivia's diversity to the optimum level prevalent in the U.S. would increase Bolivia's per capita income by a factor of 5.4, closing the income gap between the U.S. and Bolivia from a ratio of 12:1 to 2.2:1, and (v) decreasing Ethiopia's diversity to the optimum level of the U.S. would increase Ethiopia's per capita income by a factor of 1.7 and thus close the income gap between the U.S. and Ethiopia from a ratio of 47: 1 to 27:1" (Ashraf and Galor 2013). 
As it is the outcome variable in their historical models, accurate estimates of population density are crucial to demonstrating the validity of their theory. A closer examination of the data used by Ashraf and Galor reveals that these population density estimates are inaccurate. For the Americas, in particular, the population density estimates they use are strikingly lower than most values in the archaeological literature.

Ashraf and Galor (2013) derive their estimates of population size from a poor and outdated source (McEvedy and Jones 1978). They then divide these population estimates by modern national boundaries. With regard to data from the Americas, McEvedy and Jones (1978) provide no citations for how they have derived their population estimates for $1 \mathrm{CE}$ and 1000 CE. Despite well-known problems with estimating population density using both archaeological and historical data (Cook 1981), ${ }^{3}$ there is no discussion of potential error.

For example, McEvedy and Jones (1978:292) argue that the total population in Mexico in $1500 \mathrm{CE}$ was no more than 5 million. They do so based on data from Rosenblat (1945, 1967), a source that uses problematic postconquest records. In fact, scholars contemporary with McEvedy and Jones (1978) proposed estimates in the 5-6 million range for the area corresponding only to the Aztec empire (e.g., Sanders and Price 1968). The Aztecs controlled a territory that covered no more than one quarter of contemporary Mexico and that excluded all of northwest Mexico and the Yucatán. Even while, at the time McEvedy and Jones (1978) were writing, other estimates for Mexico's population were set at around 18-30 million (Cook and Borah 1971), McEvedy and Jones (1978: 272) discredit those estimates on the puzzling claim that they were not in line with those of other populations at "comparable levels of culture." More recently, Denevan (1992b: 291) has suggested that the population size within the current boundaries of Mexico reached over 21 million. For central Mexico alone, Lovell (1992b) and Denevan (1992a) summarize estimates that range from 25.2 million on the high side to 13.8 million on the low side. ${ }^{4}$

Population estimates in McEvedy and Jones rely heavily on sources that derive their data from the memoirs of the Conquistadors, none of whom were demographers. Using historical census data for population numbers in the Americas is fraught with problems. The Spanish did not carry out the first detailed inventory of labor and landholdings until half a century after the conquest of New Spain (1521), with the compilation of the 1579-1581 Relaciones Geográficas (Acuña

3. In particular, archaeological work has tended to focus on large and visible city centers, making it difficult to estimate population numbers in rural areas.

4. Humorously, one of the two most populous cities in the Americas in $1000 \mathrm{CE}$, as defined in Ashraf and Galor's table A3, is the "Classic Maya" city of "Tollan, Mexico." Tollan is a mythical place name used by the Aztecs to refer to great ancient cities (Carrasco 1992). The historicity of Great Tollan has been widely debated; it is possible that it may refer to the postclassic Toltec site of Tula (Carrasco 1992).
1984). By that time, at least nine epidemics (primarily smallpox, influenza, measles, mumps, and epidemic typhus) had torn through these densely populated territories. It is unknown how these epidemics affected native population sizes, but contemporary Spanish sources suggest it reduced the population significantly (de Sahagún 1950-1982 [c. 15451590], 1956). The Relaciones Geográficas, for example, describe numerous ghost towns, and there may have been mortality rates as high as $60 \%-90 \%$ for each individual epidemic (de Motolinía o Benavente 1971 [1540]; Prem 1992). The 1500 CE data in McEvedy and Jones (1978) do not account for these factors and, consequently, misrepresent the population estimates for pre-Columbian Mexico.

For the rest of Central America, including Guatemala, Belize, El Salvador, Honduras, Nicaragua, Costa Rica and Panama, McEvedy and Jones (1978:294) estimate a total population size of only 800,000 in CE 1500. Population estimates for Guatemala alone in 1520 range from early, very conservative estimates of 300,000 (de Solano 1974) to more recent estimates of over 2 million (Lovell 1992a). Similar problems affect population size estimates for South and North America. McEvedy and Jones (1978:309) estimate that the total population of Peru was 2 million in CE 1500. However, a more exhaustive study by Cook (1981:113) estimates the population of Peru at CE 1520, a decade prior to the Spanish conquest, as being between 5.5 and 9.4 million. Some models give a figure as low as 4 million, while others have estimates as high as 14-15 million (Cook 1981:113), but no sources have estimates for pre-Columbian Peru as low as those provided by McEvedy and Jones.

The lack of data on smaller archaeological sites dispersed throughout the continent further reduces these estimates. For North America (excluding Mexico), this is particularly problematic. To arrive at their population estimates for North America at ca. CE 1500, McEvedy and Jones (1978:286-289) use data from an outdated source (Mooney 1928). Here again, the lack of any citations for their population estimates ca. CE 1 or 1000 lead us to believe that these are indeed numbers from nowhere. In addition to providing an uncritical reading of historical sources, McEvedy and Jones (1978), and by extension Ashraf and Galor (2013), have ignored empirical and theoretical advances in North American archaeology over the last century. While they recognize that high population densities existed in certain communities across the vast territory of the modern United States, these are severely underestimated by calculating population density using the entire surface area of the modern nation-state. If they were to carry out a more accurate analysis, boundaries corresponding to the extent of ancient polities should have been drawn around sites. As a result of factual errors and uncritical analyses, it is unclear if any of the data used by Ashraf and Galor for population estimates in the Americas before $2000 \mathrm{CE}$ have any connection to reality. We challenge Ashraf and Galor to provide primary evidence for these population estimates. 
Problems with correction factors. One of the striking features of the Ashraf and Galor paper is its extensive use of basic regression models (including models constructed with migratory distance as an instrumental variable for genetic diversity) and various corrections for confounding variables. Ashraf and Galor believe that the inclusion of these factors, detailed in appendix F of their paper, strengthens their claim that there is a causal relationship between genetic diversity and economic development. We argue, however, that the controls they use are inadequate empirically.

The "Log Neolithic transition timing" is based on data from Putterman (2008), a source that does not take into account current data and debates in the field. For instance, Putterman (2008) gives a start date for the origin of agriculture in Mexico at 4,100 years ago, a datum that contradicts over a decade of archaeological research in the region. In fact, the earliest domesticated maize in Mexico has been radiocarbon dated to cal. 6250 BP (Piperno and Flannery 2001). Similarly, estimates of start dates for agriculture at 9,000 years ago no longer apply to southern China, where we now believe foragers only began to plant rice 2,000 years later (Fuller et al. 2009), and there is a complete disregard for recent work detailing early East African animal domestication (e.g., Marshall and Hildebrand 2002).

Additional problems exist with how the authors have "corrected" for land suitability for agriculture. The authors use a measure described by Ramankutty et al. (2002), the "land suitability index," which incorporates climate, moisture, and soil data. Using these criteria, Ramankutty et al. (2002:388) identify the Amazon as an area that has great potential for cropland given that these factors intersect in an ideal fashion in this area. As a result, correcting for land suitability using this index would not take into account the fact that a large portion of Brazil is covered by the Amazonian rainforest, an ecozone whose agricultural potential and preconquest population density have been much in dispute in recent years (Heckenberger et al. 2008).

Tropical forests have historically only supported very small population densities as they present a number of important nutritional challenges (Bailey and Headland 1991; Bailey et al. 1989). Although tropical forests have a high biomass, studies in behavioral ecology indicate that they are specifically lacking in carbohydrates (namely tubers), and that species that do contain carbohydrates are widely dispersed, meaning that travel times to acquire them are long and costly (Bailey et al. 1989:60-61). Acquiring food in these environments is highly unpredictable owing to fluctuations and difficulty of access in terms of space and time (Bailey et al. 1989). As a consequence, the corrections Ashraf and Galor apply to account for geography are not always appropriate and sometimes lead to an overestimation of potential areas for population growth.

Problems with the selection of genetic data. Ashraf and Galor have included genetic diversity (heterozygosity) data for only four populations from the Americas: two from Mexico, one from Colombia, and one from Brazil. These populations were selected from a subset of the HGDP-CEPH data set (Cann et al. 2002); however, genetic diversity data from many more American populations have subsequently become available. In their bibliography, Ashraf and Galor (2013) cite Wang et al. (2007), a study that provides heterozygosity data for an additional 24 populations in the Americas, but they do not incorporate these data into their analysis. Why did they choose to analyze only four populations from the Americas, while also including over twice as many populations from Europe, Asia, and Africa? In fact, heterozygosity in the Americas is locally variable but shows few overall trends. For example, an extant local Quechua-speaking community from Peru was estimated by Wang et al. (2007) to have greater heterozygosity than the Chipewyan of Canada. This suggests that Ashraf and Galor rely on a highly biased and selective use of available genetic data without justification.

Further problems are apparent upon closer inspection of the four American populations selected for analysis by Ashraf and Galor (2013). In their figure 3 ("Observed Genetic Diversity and Population Density in $1500 \mathrm{CE}$ "), the line of best fit seems to be entirely anchored by the Brazilian ("BRA") sample. The Brazilian data in this study are from the Karitiana, a small and vulnerable community in the Amazonian rainforest (Callegari-Jacques et al. 1994). Because the rainforest has constrained Karitiana population sizes, there is a greater loss of variation through genetic drift than that typical for Native American populations; this results in Karitiana homozygosity levels that are unusually high $(>0.44)$. The Karitiana do not reflect the genetic diversity of greater Brazil. If Ashraf and Galor had instead selected genetic diversity data from non-rainforest-dwelling indigenous Brazilian populations, such as the nomadic Kaingang and Guarani (Luiza et al. 1993), the estimated homozygosity would be $<0.38$, a level comparable to local populations throughout Central and South America (Wang et al. 2007). The fact that the Karitiana seem to anchor the line of best fit in figure 3 should have alarmed Ashraf and Galor, given that Ramachandran et al. (2005, fig. 2) had identified this as "the population whose removal from the data alters the regression by the greatest amount."

\section{Simplistic Assumptions about the Nature of Human Behavior}

Cooperation. To support the claim that genetic heterogeneity "increases the likelihood of miscoordination and distrust, reducing cooperation and disrupting the social order," (Ashraf and Galor 2013), the authors rely on data from a single question concerning trust on the World Values Survey and several animal cooperation studies described in their appendix H (Griffin and West 2003; Russell and Hatchwell 2001; Schneider and Bilde 2008). These studies emphasize the importance of kin selection in encouraging cooperative behaviors; that is, individuals cooperate more with close genetic 
relatives. The authors fail to account both for the animal literature in which biological kinship does not predict cooperation (Clutton-Brock 2002, 2009; West, Griffin, and Gardner 2007) and for the vast literature on human cooperation.

For more than $95 \%$ of the time since Homo sapiens evolved, humans lived in societies of hunter-gatherers for whom cooperation and sharing were essential survival mechanisms (Kramer and Ellison 2010). Recent analyses of contemporary hunter-gatherer coresidence patterns in the Hadza of Tanzania indicate that highly cooperative "bands," in which individuals share food, child care, construction, transportation of dwellings, and provisioning of public goods, are often composed of unrelated individuals (Hill et al. 2011). This evidence indicates that close genetic relationships are not requisite for sustained cooperation among humans.

Cooperation is not restricted to the Hadza but is present cross-culturally in the form of extensive food sharing, a behavior unusual among mammals and, among primates, unique to humans (Isaac 1978). Food sharing has been studied in many societies around the globe, including the Ache (Kaplan and Hill 1985), the Hiwi (Gurven et al. 2000), the Maya (Kramer 2005), the Hadza (Hawkes, O'Connell, and Jones 2001), the Dolgan and Nganasan (Ziker 2007), and fishing villages in Indonesia (Nolin 2010), among others. Studies of human cooperation in foraging societies have explicitly tested kin selection against other explanations for human cooperative behavior, such as reciprocity, alleviation of risk inherent in specialization, and mate acquisition (Gurven 2004a; Hawkes 1991; Kaplan et al. 2012; Nolin 2010). While kin selection is an important factor, it is not sufficient to explain all aspects of human food-sharing behavior. Food sharing does not vary in a way that would suggest genetic homogeneity is a causal factor in this cooperative behavior. In fact, variation in food sharing has been associated with factors including the size of the food package and the frequency of successful acquisition: large, infrequent items such as whales or large game are more likely to be shared widely (Alvard and Nolin 2002; Gurven 2004b; Kaplan et al. 2012). In sum, anthropological work has demonstrated that kin selection (genetic homogeneity) is not sufficient to explain food sharing within human societies, and variance between societies is best explained by the size and frequency of food-item acquisition.

In recent years, anthropologists have also become interested in the use of economic tools such as the public-goods game to explore cooperative behaviors in human societies. Apicella et al. (2012) have demonstrated that Hadza social networks and cooperative tendencies have the empirical regularities also found in industrialized, technologically advanced societies. Researchers have also investigated cooperative tendencies and sharing among the Ju/'hoan (Wiessner 2009), the Maasai (Aktipis, Cronk, and de Aguiar 2011), the Ache (Gurven and Winking 2008), and the Tsimane (Gurven 2004a), among others. While some caution should be exercised when using economic games to gain insight into cooperative behaviors
(Gurven and Winking 2008), the available evidence indicates that variation in cooperative behaviors exists both within and between societies (Apicella et al. 2012; Cronk 2007; Gurven, Zanolini, and Schniter 2008; Henrich et al. 2001). In addition, in cross-cultural comparisons of economic trust game behavior, geographic region does not appear to be correlated with results (Henrich et al. 2001).

The above examples only begin to introduce the extensive theoretical and empirical literature in biological anthropology and related fields concerning human cooperation and trust. Despite the existence of this literature, Ashraf and Galor use data from a single question administered as part of the World Values Survey (WVS) to analyze how trust and cooperation vary across human societies. It is not clear that this single question ("Generally speaking, would you say that most people can be trusted or that you cannot be too careful in dealing with people?") is relevant for understanding evolutionary or genetic theories of human cooperation. Although sampled at the level of individuals within countries, the authors aggregate this measure to the country level, ignoring the intracountry variation and neglecting the sampling uncertainty of such measures. Moreover, the authors aggregate this measure over time, ignoring the fact that many countries were sampled at multiple time points. As a single aggregated summary without systematic reference to intracountry or temporal variability, their measure of trust and cooperation reflects a misunderstanding of the strengths (and weaknesses) of cross-cultural survey data.

Innovation. Ashraf and Galor's theoretical model argues that genetic diversity can play a positive role in the expansion of a society's "production possibility frontier" or its ability to innovate. In their appendix $\mathrm{H}$, they use animal studies to justify this claim. They describe studies on insects that link genetic diversity to disease resistance and to several aspects of hive performance in honeybees (Seeley and Tarpy 2007; Tarpy 2003). The two bee studies cited by Ashraf and Galor correlate genetic diversity with bee foraging rates and hive temperature and indicate that disease susceptibility relates to inbreeding. Another cited insect study on fruit flies (Drosphila species) shows that genetic diversity helps increase resistance to environmental changes (Frankham et al. 1999). It is unclear how either of these relates to an ability to innovate. Perhaps Ashraf and Galor were inspired to use these data because there is no research demonstrating that genetic heterozygosity at the population level is associated with capacity to innovate.

In addition, these cross-species comparisons of genetic diversity seem to not take into account how genetic diversity varies widely among species. Humans are noted for having extremely low levels of genetic diversity compared to other animals, including our closest cousins, chimpanzees. In fact, some chimpanzee breeding groups, such as those in the Tai forests of West Africa, are estimated to have greater nucleotide diversity than the entire human species (Gagneux et al. 1999). It is important to put into perspective that the total amount 
of human genetic diversity is actually quite small compared to that found in other model organisms.

Despite this lack of research, Ashraf and Galor attempt to demonstrate that genetic heterozygosity is associated with increased propensity to innovate in humans by regressing the number of scientific articles published per year, per capita, onto their predicted genetic diversity values. Using the number of scientific publications per capita as a cross-cultural indicator of innovation is problematic. The number of scientific articles published by a nation is closely tied to a nation's particular history, especially influence from European intellectual practices. Additional factors likely include the amount of government funding allocated to research and high degrees of economic specialization. The inclusion of the control variables such as "years of schooling" is not an adequate control for underlying factors besides genetic diversity.

Historical flaws also exist in Ashraf and Galor's treatment of concepts of innovation in table A3. Here the achievements of the diverse populations at Cordoba are taken to stand for measures of "European" innovation at 1000 CE. It is misleading to use Cordoba as a measure of European success, given that it was ruled by North African Moors until 1236 CE. Likewise, it seems inconsistent to classify Constantinople as part of Europe in $1000 \mathrm{CE}$ but part of Asia in $1500 \mathrm{CE}$ (Ashraf and Galor 2013, table A3). It should also be remembered that Europe's role in innovation is a very recent phenomenon. Indeed, if we are to look for traces of "innovation" according to Ashraf and Galor's standards in Europe, archaeology has made it clear that agriculture was not independently invented in Europe, but rather spread there from the Near East (Bellwood 2006). One can also show that Renaissance Europe was heavily influenced by Greek and Arab thought (Lewis 2009; Saliba 2007). Clearly, there is a great deal of multicontinental interaction in the circum-Mediterranean region. If one excluded these data coming from the heavily African- and Middle Eastern-influenced Mediterranean region, population levels (and hence innovation levels, according to Ashraf and Galor) in Europe would be low compared to other areas of the world until the late medieval period (after 1470).

\section{Conclusion}

Social scientists seeking to explain economic behavior through genetics must exercise particular caution. As Benjamin et al. (2012:656) point out, "researchers in this field hold a special responsibility to try to accurately inform the media and the public about the limitations of the science," especially in studies intended for "social-scientific interventions" (Benjamin 2010:1). Without proper methodology and data analysis standards, false positives are likely to be misunderstood as facts, and these can then be mobilized in the political arena. Ashraf and Galor's (2013) paper is based on a fundamental scientific misunderstanding, bad data, poor methodology, and an uncritical theoretical framework. While the attempt to create interdisciplinary studies that link anthropology, genetics, and economics is laudable, economists should consult with specialists in those fields to avoid making such uninformed blunders. The same should be true of the peer-review process for such interdisciplinary articles.

More egregiously, this study has the potential to cause serious harm. By claiming a causal link between the degree of genetic heterogeneity and economic development, their thesis could be interpreted to suggest that increasing or decreasing a nation's genetic (or ethnic) diversity would promote prosperity. Ultimately, this can provide fodder to those looking to justify policies ranging from mistreatment of immigrants to ethnic cleansing (especially by groups with real political power, e.g., Golden Dawn in Greece).

We are not concerned here with the authors' own social or political attitudes. Rather, we wish to emphasize the irresponsibility of bad science. In the social sciences, scientific methods are an extremely powerful tool for analyzing trends in an empirically demonstrable manner and thus have the important opportunity to guide political action. When used improperly or when it is of dubious quality, however, science can become a justification for reactionary policy. The dismal nature of economics is often appealed to when facts contradict a desired reality. However, we are not arguing a case for blissful ignorance. What we see in Ashraf and Galor's study is the worst of all worlds: something false and undesirable.

\section{References Cited}

Acuña, R. 1984. Relaciones geográficas del siglo XVI. Antequera: Universidad Nacional Autónoma de México.

Aktipis, C. A., L. Cronk, and R. de Aguiar. 2011. Risk-pooling and herd survival: an agent-based model of a Maasai gift-giving system. Human Ecology 39:131-140.

Alvard, M. S., and D. A. Nolin. 2002. Rousseau's whale hunt? coordination among big-game hunters. Current Anthropology 43(4):533-559.

Apicella, C. L., F. W. Marlowe, J. H. Fowler, and N. A. Christakis. 2012. Social networks and cooperation in hunter-gatherers. Nature 481:497-501.

Ashraf, Q., and O. Galor. 2013. The "Out of Africa" hypothesis, human genetic diversity, and comparative economic development. American Economic Review 103(1):forthcoming.

- 2012. Response to comments made in a letter by d'Alpoim Guedes et al. on "The Out of Africa hypothesis, human genetic diversity and comparative development.” http://www.econ.brown.edu/fac/Oded_Galor/ Ashraf-Galor\%20Response.pdf.

Bailey, R. C., G. Head, M. Jenike, B. Owen, R. Rechtman, and E. Zechenter. 1989. Hunting and gathering in the tropical rainforest: is it possible? American Anthropologist 91:59-82.

Bailey, R. C., and T. N. Headland. 1991. The tropical rainforest: is it a productive environment for human foragers? Human Ecology 19:261-285.

Bellwood, P. 2006. First farmers: the origins of agricultural societies. Oxford: Blackwell.

Benjamin, D., C. Chabris, E. Glaeser, V. Gudnason, and T. Harris. 2007. Genoeconomics. In Biosocial surveys. M. Weinstein, J. Vaupel, and K. Watcher, eds. Pp. 304-335. Washington, DC: National Academy.

Benjamin, D. J. 2010. White paper for NSF workshop on genes, cognition, and social behavior. http://economics.cornell.edu/dbenjamin/White $\% 20$ Paper\%202010-07-09.pdf.

Benjamin, D. J., D. Cesarini, C. F. Chabris, E. L. Glaeser, D. I. Laibson, V. Guðnason, T. B. Harris, et al. 2012. The promises and pitfalls of genoeconomics. Annual Review of Economics 4:627-662. 
Callaway, E. 2012. Economics and genetics meet in uneasy union. Nature 490: $154-155$.

Callegari-Jacques, S. M., F. M. Salzano, T. A. Weimer, M. H. Hutz, F. L. Black, S. E. B. Santos, J. F. Guerreiro, M. A. Mestriner, and J. P. Pandey. 1994. Further blood genetic studies on Amazonian diversity-data from four Indian groups. Annals of Human Biology 21:465-481.

Cann, H. M., C. de Toma, L. Cazes, M.-F. Legrand, V. Morel, and L. Pioure. 2002. A human genome diversity cell line panel. Science 296:261-262.

Carrasco, D. 1992. Quetzalcoatl and the irony of empire: myths and prophecies in the Aztec tradition. Chicago: University of Chicago Press.

Chin, G. 2012. The long shadow of genetic capital. Science 337:1150.

Clark, G. 2007. Farewell to alms: a brief economic history of the world. Princeton, NJ: Princeton University Press.

Clutton-Brock, T. 2002. Behavioral ecology-breeding together: kin selection and mutualism in cooperative vertebrates. Science 296:69-72.

. 2009. Cooperation between non-kin in animal societies. Nature 462: $51-57$.

Cook, N. D. 1981. Demographic collapse: Indian Peru, 1520-1620. Cambridge: Cambridge University Press.

Cook, S. F., and W. Borah. 1971. Essays in population history. Berkeley: University of California Press.

Cronk, L. 2007. The influence of cultural framing on play in the trust game: a Maasai example. Evolution and Human Behavior 28:352-358.

d'Alpoim Guedes, J., D. Reich, M. Herzfeld, N. Patterson, T. Bestor, D. Lieberman, J. Comaroff, et al. 2012. Response to Ashraf and Galor "The Out of Africa hypothesis, human genetic diversity and comparative economic development." http://ssrn.com/abstract $=2155060$.

de Motolinía o Benavente, T. 1971 [1540]. Memoriales o libro de las cosas de la Nueva España y de los naturales dello. México: UNAM.

Denevan, W. M. 1992a. Native American populations in 1492: recent research and a revised hemispheric estimate. In The native population of the Americas in 1492. W. M. Denevan, ed. Pp. xvii-xxxviii. Madison: University of Wisconsin Press.

- 1992b. The native population of the Americas in 1492. Madison: University of Wisconsin Press.

de Sahagún, B. 1950-1982 [c. 1545-1590]. Florentine codex: general history of the things of New Spain. Santa Fe, NM: School of American Research.

- 1956. Historia general de las cosas de Nueva España [c. 1545-1590]. Angel María Garibay K edition. Vol. 3. Mexico City: Editorial Porrua.

de Solano, F. 1974. Los Mayas del siglo XVIII. Madrid: Ediciones Cultura Hispanica.

Frankham, R., K. Lees, M. E. Montgomery, P. R. England, E. H. Lowe, and D. A. Briscoe. 1999. Do population size bottlenecks reduce evolutionary potential? Animal Conservation 2:255-260.

Fuller, D., L. Qin, Y. Zheng, Z. Zhao, X. Chen, L. Hosoya, and G. Sun. 2009. The domestication process and domestication rate in rice: spikelet bases from the Lower Yangtze. Science 323:1607-1610.

Gagneux, P., C. Wills, U. Gerloff, D. Tautz, P. A. Morin, C. Boesch, B. Fruth, G. Hohmann, O. A. Ryder, and D. S. Woodruff. 1999. Mitochondrial sequences show diverse evolutionary histories of African hominoids. Proceedings of the National Academy of Sciences of the USA 96:5077-5082.

Griffin, A. S., and S. A. West. 2003. Kin discrimination and the benefit of helping in cooperatively breeding vertebrates. Science 302:634-636.

Gurven, M. 2004a. Economic games among the Amazonian Tsimane: exploring the roles of market access, costs of giving, and cooperation on prosocial game behavior. Experimental Economics 7:5-24.

- 2004b. To give and to give not: the behavioral ecology of human food transfers. Behavioral and Brain Sciences 27:543-583.

Gurven, M., K. Hill, H. Kaplan, A. Hurtado, and R. Lyles. 2000. Food transfers among Hiwi foragers of Venezuela: tests of reciprocity. Human Ecology 28: 171-218.

Gurven, M., and J. Winking. 2008. Collective action in action: prosocial behavior in and out of the laboratory. American Anthropologist 110:179-190.

Gurven, M., A. Zanolini, and E. Schniter. 2008. Culture sometimes matters: intra-cultural variation in pro-social behavior among Tsimane Amerindians. Journal of Economic Behavior and Organization 67:587-607.

Hawkes, K. 1991. Showing off-tests of an hypothesis about men's foraging goals. Ethology and Sociobiology 12:29-54.

Hawkes, K., J. F. O'Connell, and N. G. B. Jones. 2001. Hadza meat sharing. Evolution and Human Behavior 22:113-142.

Heckenberger, Michael J., J. Christian Russell, Carlos Fausto, Joshua R. Toney, Morgan J. Schmidt, Edithe Pereira, Bruna Franchetto, and Afukaka Kuik- uro. 2008. Pre-Columbian urbanism, anthropogenic landscapes, and the future of the Amazon. Science 321:1214-1217.

Henrich, J., R. Boyd, S. Bowles, C. Camerer, E. Fehr, H. Gintis, and R. McElreath. 2001. In search of Homo economicus: behavioral experiments in 15 small-scale societies. American Economic Review 91:73-78.

Hill, K. R., R. S. Walker, M. Bozicevic, J. Eder, T. Headland, B. Hewlett, A. M. Hurtado, F. W. Marlowe, P. Wiessner, and B. Wood. 2011. Co-residence patterns in hunter-gatherer societies show unique human social structure. Science 331:1286-1289.

Isaac, G. L. 1978. Food sharing and human evolution: archeological evidence from the Plio-Pleistocene of east-Africa. Journal of Anthropological Research 34:311-325.

Kaplan, H., and K. Hill. 1985. Food sharing among Ache foragers: tests of explanatory hypotheses. Current Anthropology 26(2):223-246.

Kaplan, H. S., E. Schniter, V. L. Smith, and B. J. Wilson. 2012. Risk and the evolution of human exchange. Proceedings of the Royal Society B: Biological Sciences 279:2930-2935.

Kramer, K. 2005. Maya children: helpers at the farm. Cambridge, MA: Harvard University Press.

Kramer, K., and P. Ellison. 2010. Pooled energy budgets: resituating human energy allocation trade-offs. Evolutionary Anthropology 19:136-147.

Lewis, D. L. 2009. God's crucible, Islam and the making of Europe, 570-1215. New York: W. W. Norton.

Lovell, G. 1992a. Disease and depopulation in early colonial Guatemala. In Secret judgements of God: Old World disease in Colonial Spanish America. N. D. Cook and W. G. Lovell, eds. Pp. 49-83. Norman: University of Oklahoma Press.

. 1992b. "Heavy shadows and black night": disease and depopulation in colonial Spanish America. Annals of the Association of American Geographers 82:426-443.

Luiza, M., P. Erler, R. Luz, and V. S. Sotomaior. 1993. The HLA polymorphism of two distinctive South-American Indian tribes: the Kaingang and the Guarani. Tissue Antigens 41:227-237.

Marshall, F., and E. Hildebrand. 2002. Cattle before crops: the beginnings of food production in Africa. Lournal of World Prehistory 16:99-143.

McEvedy, C., and R. Jones. 1978. Atlas of world population history. New York: Penguin.

Meyer, M., M. Kircher, M. T. Gansauge, H. Li, F. Racimo, S. Mallick, J. G. Schraiber, et al. 2012. A high-coverage genome sequence from an archaic Denisovan individual. Science 338(6104):222-226.

Mooney, J. 1928. The Aboriginal population of America north of Mexico. Smithsonian Miscellaneous Collections 80(2955):1-41.

Nolin, D. A. 2010. Food-sharing networks in Lamalera, Indonesia reciprocity, kinship, and distance. Human Nature 21:243-268.

Piperno, D. R., and K. V. Flannery. 2001. The earliest archaeological maize (Zea mays L.) from highland Mexico: new accelerator mass spectrometry dates and their implications. Proceedings of the National Academy of Sciences of the USA 98:2101-2103.

Prem, H. 1992. Disease outbreaks in central Mexico during the sixteenth century. In Secret judgments of God: Old World disease in colonial Spanish America. N. Cook and W. Lovell, eds. Pp. 20-48. Norman: University of Oklahoma Press.

Putterman, L. 2008. Agriculture, diffusion, and development: ripple effects of the Neolithic revolution. Economica 75:729-748.

Ramachandran, S., O. Deshpande, C. C. Roseman, Noah A. Rosenberg, M. W. Feldman, and L. L. Cavalli-Sforza. 2005. Support from the relationship of genetic and geographic distance in human populations for a serial founder effect originating in Africa. Proceedings of the National Academy of Sciences of the USA 102:15942-15947.

Ramankutty, N., J. A. Foley, J. Norman, and K. McSweeney. 2002. The global distribution of cultivable lands: current patterns and sensitivity to possible climate change. Global Ecology and Biogeography 11:377-392.

Rosenblat, A. 1945. La poblacion indigena de America desde 1492 hasta la actualidad. Buenos Aires: Institucion Cultural Espanola.

. 1967. La poblacion America en 1492: viejogs y nuevos calculos. Mexico: El Colegio de Mexico.

Russell, A. F., and B. J. Hatchwell. 2001. Experimental evidence for kin-biased helping in a cooperatively breeding vertebrate. Proceedings of the Royal Society B: Biological Sciences 268:2169-2174.

Saliba, G. 2007. Islamic science and the making of the European renaissance. Cambridge, MA: MIT Press.

Sanders, W. T., and B. J. Price. 1968. Mesoamerica: the evolution of a civilization. New York: Random House.

Schneider, J. M., and T. Bilde. 2008. Benefits of cooperation with genetic kin 
in a subsocial spider. Proceedings of the National Academy of Sciences of the USA 105:10843-10846.

Seeley, T. D., and D. R. Tarpy. 2007. Queen promiscuity lowers disease within honeybee colonies. Proceedings of the Roval Society B: Biological Sciences 274: $67-72$.

Tarpy, D. R. 2003. Genetic diversity within honeybee colonies prevents severe infections and promotes colony growth. Proceedings of the Roval Society $B$ : Biological Sciences 270:99-103.

Wang, S., C. M. Lewis Jr., M. Jakobsson, S. Ramachandran, N. Ray, G. Bedoya,
W. Rojas, et al. 2007. Genetic variation and population structure in Native Americans. PLoS Genetics 3:e185.

West, S. A., A. S. Griffin, and A. Gardner. 2007. Evolutionary explanations for cooperation. Current Biology 17:R661-R672.

Wiessner, P. 2009. Experimental games and games of life among the Ju/'hoan Bushmen. Current Anthropology 50(1):133-138.

Ziker, J. P. 2007. Subsistence and food sharing in northern Siberia: social and nutritional ecology of the Dolgan and the Nganasan. Ecology of Food and Nutrition 46:445-467. 